coccal antibody titre; and (d) clinical signs of meningococcal meningitis or septicaemia.

Of the 109 patients, 92 were admitted to hospital by their general practitioner, 13 were admitted through the accident and emergency department, three were found dead at home, and one was admitted after a domiciliary visit by a consultant paediatrician. Parenteral penicillin was given to 23 patients $(21 \%)$ either by their general practitioner or by a casualty officer. A further seven patients had been taking oral antibiotics before presentation. During 1989, after the chief medical officer's recommendation about early use of penicillin ${ }^{3}$ and widespread media coverage of a cluster of cases in this district, 14 of 27 patients $(52 \%)$ received penicillin before admission. Excluding the patients who had been taking oral antibiotics before presentation, the overall case fatality rate during our study was $12 \%$ (one of the 23 patients $(4 \%)$ given early penicillin died compared with 11 of the $79(14 \%)$ not given it)

The frequency of early use of penicillin in suspected cases of meningococcal disease in our study was similar to that found by Strang and Pugh and Cartwright and colleagues. Early parenteral penicillin was associated with reduced mortality, and, although this was not significant, it is consistent with the trend observed by these other workers. General practitioners need to be continually reminded of the value of early treatmen with parenteral penicillin whenever meningococcal disease is suspected.

S GOSSAIN

C. E CONSTANTINE J M WEBBERIEY

Department of Microbiology,

Worcester Royal Infirmary

Worcester WRI 3AS

1 Strang JR, Pugh EJ. Meningococcal infections: reducing the case fatality rate by giving penicillin before admission to hospital. BMF 1992;305:141-3. (18 July.)

2 Cartwright K, Reilly S, White D, Stuart J. Early treatmen with parenteral penicillin in meningococcal disease. $B M 7$ with parenteral penicillin

3 Department of Health and Social Security. Meningococcal infection: meningitis and septicaemia. London: HMSO, 1988. $(\mathrm{CMO}(88) 2$.

\section{Giant cell arteritis}

EdIToR,-Justin C Mason and Mark J Walport suggest that $\mathrm{C}$ reactive protein concentration may be a more effective marker of disease activity in giant cell arteritis than the erythrocyte sedimentation rate.' The study they cite was of 13 patients with polymyalgia rheumatica, and $\mathrm{C}$ reactive protein concentration reflected disease activity more accurately over the first two weeks of treatment. ${ }^{2}$ We carried out a prospective study of 74 patients and found that the erythrocyte sedimentation rate correlated better than $\mathrm{C}$ reactive protein concentration with disease activity. ${ }^{3}$ The $\mathrm{C}$ reactive protein concentration fell more rapidly in the first two weeks after treatment, but assessing response at this stage is rarely difficult. Thereafter the erythrocyte sedimentation rate was a better marker.

I suggest, therefore, that in most circumstances the erythrocyte sedimentation rate could be safely used to monitor disease activity in polymyalgia rheumatica and giant cell arteritis.

Department of General Medicine,

V KYLE

Frenchay Hospital,
Bristol BS16 ILE

1 Mason JC, Walport MJ. Giant cell arteritis. BMf 1992;305:68-9 (11 July.)

2 Mallya RK, Hind CR, Berry H, Pepys MB. Serum C-reactive protein in polymyalgia rheumatica. A prospective serial study. Ann Rheum 1985;28:383-7.

3 Kyle V, Cawston TE, Hazleman BL. ESR and C-reactive protein in the assessment of polymyalgia rheumatica-riant cell arteritis on presentation and during follow up. Ann Rheum Dis 1989:48: $667-71$.
EDITOR, - By considering giant cell arteritis from a rheumatologist's viewpoint Justin C Mason and Mark J Walport make several statements in their editorial that are probably not applicable generally and certainly not applicable to giant cell arteritis causing visual loss.' The sensitivity of temporal artery biopsy is much higher than $60 \%$ : it correctly predicts the need for corticosteroid treatment in $94 \%$ of cases ${ }^{2}$ and should be regarded as crucial to management.

Doctors have recourse to diagnostic methods other than "mystery and mystique." In ischaemic optic neuropathy both ocular pneumoplethysmography and appreciably delayed choroidal filling on fluorescein angiography are extremely useful in differentiating ischaemia due to giant cell arteritis from that due to non-arteric causes. ${ }^{34}$ Systemic markers of the underlying immunological disturbance can also be sought: both raised levels of IgG anticardiolipin antibodies and selective depletion of CD8+ lymphocytes in the peripheral blood are reliable. ${ }^{56}$

The authors' advice on treatment, particularly for patients with visual loss, should be treated circumspectly. Graham et al's recommendation of $250 \mathrm{mg}$ of intravenous hydrocortisone at presentation coupled with a starting dose of $80 \mathrm{mg}$ of prednisolone orally, reducing to $30 \mathrm{mg}$ over the first 10 days, is the standard regimen. ${ }^{7}$ Regimens of lower steroid doses are more suited to the treatment of polymyalgia rheumatica, especially as inadequate steroid treatment has been identified as a possible factor in death in the acute phase of giant cell arteritis. ${ }^{8}$ Although use of inadequate steroid doses is to be deprecated, recommendations to use high dose intravenous pulses of steroid in acute visual loss are not based on convincing evidence. Monitoring the withdrawal of steroids by measuring the erythrocyte sedimentation rate is unreliable, ${ }^{10}$ and a better approach is to use a fixed withdrawal regimen.' During a fixed withdrawal regimen the recurrence of symptoms or signs should be monitored (and the dose of steroids increased to the dose that previously controlled the recurrent features) and CD8+ lymphocyte counts measured serially."

LOUIS G CLEARKIN

Barnsley District General Hospital,

Barnslev S75 2EP

1 Mason JC, Walport MJ. Giant cell arteritis. BMf 1992;305: 68-9. (11 July.)

2 Hall S, Lie JT, Kurland LT, Persellin S, O'Brien PC, Hunder GG. The therapeutic impact of temporal artery biopsy. Lancet 1983;ii: 1217-20.

3 Mack HG, O'Day J, Currie JN. Delayed choroidal perfusion in giant cell arteritis. $\mathcal{F}$ Clin Neuro-Ophthalmol 1992;11:221-7.

4 Bosley TM, Savino PJ, Sergott RC, Eagle RC, Sandy R, Gee W Ocular pneumoplethysmography can help in the diagnosis of giant-cell arteritis. Arch Ophthalmol 1989;107:379-81.

5 Watts MT, Greaves M, Clearkin LG, Malia RG, Cooper S. Antiphospholipid antibodies and ischaemic optic neuropathy. Lancet 1990;335:613-4.

6 Dasgupta B, Duke O, Timms AM, Pitzalis C, Panayi GS. Selective depletion and activation of CD8+ lymphocytes from the peripheral blood of patients with polymyalgia rheumatica and giant cell arteritis. Ann Rheum Dis 1989;48: ro7-11.

7 Graham E, Holland A, Avery A, Russell RWR. Prognosis in giant cell arteritis. BMF 1981;282:269-71.

8 Save-Soderberg J, Malmvall BE, Anderson R, Bengtsson BA. Giant cell arteritis as a cause of death. $\mathcal{F A M A} 1986 ; 255: 493-6$. 9 Clearkin LG, Caballero JC. Recovery of visual function in anterior ischemic optic neuropathy due to giant cell arteritis. Am F Med 1992;92:703-4.

10 Ellis ME, Ralston S. The ESR in the diagnosis and management of the polymyalgia rheumatica/giant cell arteritis syndrome. Ann Rheum Dis 1983;42:168-70.

11 Clearkin LG, Watts MT. Ocular involvement in giant cell arteritis. Brf Hosp Med 1990;43:373-6.

AUTHORS' REPLY,-Referral bias means that ophthalmologists, rheumatologists, and general practitioners each see a different part of the large clinical range of severity of giant cell arteritis. Ophthalmologists see a higher proportion of patients presenting with visual loss and therefore requiring more aggressive treatment. As far as diagnosis is concerned, we do not question the importance of temporal artery biopsy. Such biopsies, however, yield negative results in up to one third of patients with symptoms suggestive of giant cell arteritis, with false negative rates of $10-61 \%$ reported. $^{\prime}$

We question the value of raised levels of anticardiolipin antibodies and reduced $\mathrm{CD} 8+$ lymphocyte counts both as diagnostic tools and as a means of monitoring disease activity in giant cell arteritis. Anticardiolipin antibodies may be a marker of a small subset of patients with ischaemic optic neuropathy as part of the antiphospholipid syndrome. ${ }^{23}$ There is no evidence that the CD8+ lymphocyte count is any more than a very expensive indirect correlate of the acute phase response. ${ }^{4}$

The prescription of high dose corticosteroid regimens in patients with giant cell arteritis presenting with visual loss is not in dispute, though no "gold standard" regimen exists. There is, however, evidence to support lower initial doses of corticosteroids in patients without visual loss, and these do not seem to be associated with an increased risk of relapse. There is no reliable method of predicting which patients will relapse while taking steroids ${ }^{6}$ and recurrence of severe disease in patients taking stable doses of steroids is well described. ${ }^{7}$ Too rapid a reduction in the dose of corticosteroids is probably the main risk factor. We therefore favour a gradual reduction of treatment, not confined to a fixed regimen but dictated by careful and frequent monitoring of the patient's symptoms and acute phase response.

JUSTIN C MASON MARK J WALPORT

Royal Postgraduate Medical School,

London W120NN

1 Ashton-Key M, Gallagher PJ. Surgical pathology of cranial arteritis and polymyalgia rheumatica. In: Hazleman B, Bengtsson B, eds. Giant cell arteritis and polymyalgia rheumatica. London: Baillière Tindall, 1991:387-404.

2 Mackworth-Young CG, Loizou S, Walport MJ. Antiphospholipid antibodies and disease. Qf Med 1989;72:767-77.

3 Watts MT, Greaves M, Clearkin LG, Malia RG, Cooper SM. Anti-phospholipid antibodies and ischaemic optic neuropathy. Lancet 1990;335:613-4.

4 Elling H, Elling P, Olsson A. CD8 + lymphocyte subset in polymyalgia rheumatica and giant cell arteritis. Clin Exp Rheumatol 1989;7:627-30.

5 Myles AB, Perera T, Ridley MG. Prevention of blindness in giant cell arteritis by corticosteroid treatment. $\mathrm{Br} \mathcal{F}$ Rheumatol 1992;31:103-5.

6 Vilaseca J, Gonzales A, Cid MC, Lopez-Vivancos J, Ortega A. Clinical usefulness of temporal artery biopsy. Ann Rheum Dis 1987;46:282-5.

Whitfield AGW, Bateman M, Cooke WT. Temporal arteritis. Brf Ophthalmol 1963;47:555-66.

\section{Removal of central venous catheter and venous air embolism}

EDITOR,-I share Peter Mennim and colleagues' concerns about air embolism occurring when a central venous catheter is removed and agree with their recommendations for preventing this complication. ${ }^{1}$ I first witnessed a death due to venous air embolism via a central venous catheter in 1973. ${ }^{2}$ The postmortem examination was carried out by the late Professor Keith Simpson, who coincidentally reported the first episodes of venous air embolism via transfusion equipment. ${ }^{3} \mathrm{He}$ mentioned that he had seen several other deaths due to air embolism via central venous catheters and criticised the integrity of the devices. Unfortunately, little has changed during the past 20 years.

The incidence of important air embolism associated with central venous catheters is, however, much higher than the authors suggest. I have been carrying out a regular search of published work for several years: to date 151 cases in which cardiorespiratory distress or considerable neurological morbidity occurred have been reported and 